\title{
PELAKSANAAN PRINSIP KEADILAN DALAM PERIKATAN ANTARA LEMBAGA KEUANGAN MIKRO MILIK MASYARAKAT DENGAN DEBITUR
}

\author{
Widiastuti \\ Fakultas Hukum Universitas Slamet Riyadi \\ widiastuti.unisri@g.mail.com
}

Abstract

Micro finances are intermediary institutions generally owned by the community and managed autonomously. These study aims describe the institutions about the relationship between capital owners and debtors with community micro finances and analyze the implementation of the principle of justice contained in the engagement between financial institutions and members as capital owners or debtors. This research is a sociological legal research that analyzes primary data in the form of behavior as a living law, research conducted on 5 community-owned micro finances in 2 villages. The results of the study illustrate that the governing institution includes the management period, principal and compulsory savings, loans, interest, loan repayment provisions, settlement of problem loans. The regulations governing the relationship between micro finances and members are determined jointly by all members but have not yet implemented the principle of justice, especially in lending and loan agreements.

Lembaga keuangan mikro atau LKM merupakan lembaga intermediasi pada umumnya dimiliki masyarakat dan dikelola secara informal. Penelitian ini bertujuan menggambarkan lembaga yang mengatur hubungan antara pemilik modal dan debitur dengan LKM milik masyarakat dan menganalisis pelaksanaan prinsip keadilan yang terkandung dalam perikatan antara lembaga keuangan dengan anggota sebagai pemilik modal atau debitur. Penelitian ini merupakan penelitian hukum sosiologis yang mengkaji perilaku sebagai hukum yang hidup, penelitian dilakukan terhadap 5 lembaga keuangan mikro milik masyarakat yang ada di 2 desa. Hasil penelitian menggambarkan bahwa lembaga yang mengatur meliputi masa pengurusan, simpanan pokok dan wajib, pinjaman, bunga, ketentuan pengembalian pinjaman, penyelesaian pinjaman yang bermasalah. Lembaga yang mengatur hubungan antara LKM dengan anggota sekalipun ditentukan bersama oleh semua anggota namun belum mengimplementasikan prinsip keadilan, terutama dalam perjanjian pinjam meminjam dan pembagian keuntungan.

Key words : keadilan, lembaga keuangan mikro, kredit

\section{Pendahuluan}

Salah satu indikator kemudahan pelaksanaan bisnis atau easy doing of business disingkat OEDB adalah akses masyarakat akan kredit dan pelaksanaan perjanjian. Menurut
EODB Indonesia 2018 yang dirilis

Bank Dunia, indikator akses masyarakat dalam memperoleh kredit mengalami peningkatan peringkat dari 55 naik menjadi 44, namun data ini tidak memerinci jenis dan bentuk 
lembaga keuangan yang dapat diakses oleh masyarakat untuk mendapatkan kredit. Data tahun 2017, penduduk yang memiliki akses kredit dari perbankan hanya 36 persen ( www.berdesa.com.), sisanya dipenuhi oleh lembaga kredit non bank atau lembaga kredit informal seperti rentenir, tengkulak atau lembaga kredit online yang memberikan kemudahan akses tetapi membebani suku bungan yang relatif tinggi.

Menurut Statistik Kredit dari Bank Indonesia, jenis lembaga yang menyalurkan kredit adalah lembaga keuangan formal -seperti bank milik pemerintah, bank swasta nasional, bank swasta asing, bank syariah--. Sedangkan status debitur atau penerima kredit adalah pelaku usaha mikro, kecil, menengah dan besar (bi.go.id.). Data ini berbeda dengan data dari Databoks yang menyatakan bahwa akses masyarakat terhadap kredit masih rendah, setiap 1.000 penduduk dewasa baru 222 orang atau 22,2 persen yang mendapat akses kredit dari perbankan (Databoks). Bank Dunia menyatakan ada gap kredit yang cukup besar di Indonesia yang jumlahnya mencapai Rp. 1.000 Trilyun, Hal ini terjadi karena adanya ketidakseimbangan antara kebutuhan kredit dan institusi keuangan dalam menyediakan kredit (kontan.go.id). Gap kredit secara implisit mengandung arti bahwa ada pihak yang tidak terpenuhi kebutuhan kreditnya oleh perbankan, dan gap kredit tersebut diisi oleh lembaga keuangan mikro

Lembaga keuangan mikro, yang mempunyai peran penting dalam pembangunan ekonomi. Beberapa hasil penelitian menunjukkan bahwa berbagai bentuk lembaga keuangan mikro atau disingkat LKM yang ada di pedesaan berperan penting dalam pembangunan ekonomi pedesaan dan mengurangi kemiskinan (Parera, 2010). Menurut UU No 1 Tahun 2013 tentang LKM, pengertian LKM adalah adalah lembaga keuangan yang khusus didirikan untuk memberikan jasa pengembangan usaha dan pemberdayaan masyarakat, baik melalui pinjaman atau pembiayaan dalam usaha skala mikro kepada anggota dan masyarakat, pengelolaan simpanan, maupun pemberian jasa konsultasi pengembangan usaha yang tidak semata-mata mencari keuntungan.

Bentuk badan usaha LKM juga bermacam-macam, ada yang berbadan hukum seperti LKM Bank, LKM Koperasi, ada pula LKM yang tidak berbadan hukum yang didirikan dan dikelola oleh komunitas, dan LKM tidak berbadan hukum yang didirikan berdasarkan SK Bupati. (Handayana dan Bustaman, 2007). Belum lagi LKM yang masuk kategori informal selain tidak berbadan hukum, 
pembentukannya tidak didasarkan pada SK Bupati/Walikota.

Pengalaman penyelenggaraan LKM di negara-negara berkembang, peran LKM tidak hanya sebagai lembaga intermediasi tetapi juga berperan mengurangi kemiskinan dan menumbuhkan modal sosial. Salah satu LKM yang berhasil mengurangi kemiskinan adalah Grameen Microfinance di Bangladesh. Lembaga keuangan ini menyediakan pinjaman kepada kelompok paling miskin untuk kegiatan produktif, tanpa adanya jaminan (collateral) berbentuk benda fisik, tetapi mensyaratkan adanya jaminan sosial yang berasal dari kelompok (Shahidur et.al, 1995). Di Indonesia misal lembaga perkreditan kecamatan atau LPK. Lembaga ini menawarkan pinjaman tanpa jaminan, dan memberi sanksi denda bagi peminjam yang terlambat mengembalikan pinjaman. Modal LPK dari pemerintah dan simpanan wajib anggota, dan tidak menerima simpanan sukarela dari anggotanya (Bakasra, 2010).

Sekalipun LKM memiliki peran penting dalam pembangunan ekonomi kelompok kelas bawah, namun tidak sedikit yang mengalami kegagalan atau bubar, ada berbagai hal yang menyebabkan LKM gagal atau tidak berlanjut diantaranya, adanya kredit yang tidak kembali. Sebagaimana temuan tentang kredit yang disalurkan melalui LKM dengan prinsip syariah yang mengandung resiko tinggi, yang diwujudkan oleh kegagalan pengembalian kredit, yang pada akhirnya mengganggu keberlanjutan LKM ( Mulayaningsih, et.al, 2006).

Salah satu LKM nonformal adalah LKM milik komunitas adalah kelompok simpan pinjam yang dimiliki dan dikelola oleh masyarakat. LKM ini hampir dapat ditemukan di setiap lingkungan rukun tetangga atau kelompok sosial yang dibentuk oleh warga. Sistem permodalan lembaga keuangan ini mirip koperasi, yaitu berasal dari anggota dan disalurkan sebagai pinjaman kepada anggota. LKM ini menjalankan fungsi sebagai intermediasi yaitu menghimpun dana dari anggota, atau pihak lain dan menyalurkan kembali sebagai kredit kepada anggota juga. Jangkauan lembaga keuangan ini terbatas pada anggota yang memiliki hubungan tetap.

Lembaga keuangan yang berbentuk seperti itu tidak mendapat pengawasan dari otoritas keuangan, karena diposisikan sebagai kelompok usaha yang otonom. Lembaga keuangan milik masyarakat ini menarik untuk diteliti karena pengelolaan dilakukan secara informal, didasarkan ikatan sosial, sehingga jika ada kerugian harus ditanggung sendiri oleh 
anggotanya atau pemilik modal. Sehubungan dengan sifat otonom dari LKM tersebut tidak sedikit lembaga keuangan tersebut bubar karena menderita rugi -akibat pinjaman yang tidak kembali maupun salah pengelolaan--, tetapi tidak sedikit yang bertahan hingga bertahun-tahun, contohnya kelompok simpan pinjam di tingkat rukun tetangga atau komunitas lainnya.

Hasil penelitian terdahulu menunjukkan bahwa lembaga keuangan mikro milik masyarakat merupakan wahana memupuk modal sosial (Feigenberg, et.al, 2010). Dalam hal ini tujuan pembentukan LKM milik masyarakat tidak hanya sebagai intermediasi, tetapi sebagai wahana pembentukan modal sosial, sehingga tetap bertahan selama modal sosial itu ada. Namun demikian penelitian tersebut belum mengungkap peraturan apa saja yang berlaku dalam lembaga keuangan mikro yang merupakan hasil modal sosial. Penelitian ini bertujuan untuk mengidentifikasi kelembagaan atau peraturan yang mengatur hubungan antara LKM milik masyarakat dan anggotanya; dan menganalisa pelaksanaan prinsip keadilan yang terkandung dalam perikatan antara lembaga keuangan dengan anggota baik sebagai penyimpan maupun peminjam

\section{Metode Penelitian}

Penelitian ini merupakan penelitian yuridis sosilogis, yang memaknai hukum sebagi perilaku nyata yang ajeg dari suatua kelompok. Data yang dikumpulkan untuk menjawab tujuan penelitian adalah data primer dalam bentuk perilaku verbal maupun nyata dari pengelola, debitur dan penyimpan dari LKM. Data primer yang terkumpul dianalisa dengan logika induktif, dan selanjutnya dikaji aspek normatif.

Guna membangun konsep LKM, perjanjian, keadilan maka dikumpulkan data sekunder, baik yang berbentuk bahan hukum maupun data sekunder non hukum. Konsep ini digunakan untuk mengidentifikasi LKM milik masyarakat, maupun peraturan tentang pengelolaan, perjanjian antara peminjam atau pemilik modal dengan LKM.

Sampel dalam penelitian ini terdiri dari 5 LKM yang beroperasi di Desa Wonorejo dan Plesungan Kecamatan Gondangrejo Kabupaten Karanganyar. Pengambilan sampel secara pusposive berdasarkan pertimbangan bahwa semuanya sudah beroperasi lebih dari 10 tahun, jangka waktu yang dapat mengukur ketahanan lembaga. Adapun berdasarkan sumber modalnya, 3 LKM dibentuk oleh masyarakat, artinya modal berasal dari dan disalurkan kepada anggota. LKM ini dibentuk berdasarkan kesepakatan 
dari anggota dan tidak dituangkan akta notriel. Sedangkan 2 LKM lainnya adalah LKM yang modalnya berasal dari pemerintah, sementara anggotanya hanya memiliki hak meminjam tidak punya kewajiban menyetor simpanan.

\section{Hasil dan Pembahasan}

Menurut UU No 1 Tahun 2013 tentang Lembaga Keuangan Mikro yang dimaksud LKM adalah lembaga keuangan yang khusus didirikan untuk memberikan jasa pengembangan usaha dan pemberdayaan masyarakat, baik melalui pinjaman atau pembiayaan dalam usaha skala mikro kepada anggota dan masyarakat, pengelolaan simpanan, maupun pemberian jasa konsultasi pengembangan usaha yang tidak semata-mata mencari keuntungan.

Kegiatan usaha LKM meliputi jasa pengembangan usaha dan pemberdayaan masyarakat, baik melalui pinjaman atau pembiayaan dalam usaha skala mikro kepada anggota dan masyarakat, pengelolaan simpanan, maupun pemberian jasa konsultasi pengembangan usaha. Definisi ini merupakan definisi formal yang dirumuskan oleh Otoritas Jasa Keuangan. Jika mengacu pada unsur LKM, maka kelompok simpan pinjam yang dibentuk masyarakat tidak dapat dikategorikan sebagai LKM karena tidak memiliki unsur pemberian jasa konsultasi pengembangan usaha. Artinya bahwa pinjaman yang diberikan oleh kelompok simpan pinjam tidak disyaratkan untuk pengembangan usaha.

Unsur dari LKM adalah adanya fungsi intermediasi yang diimplementasikan dalam bentuk mengelola modal, baik itu berasal dari anggota atau pihak ketiga, dan menyaluran pinjaman kepada anggota. LKM sebagai lembaga yang berfungsi intermediasi berkewajiban memberikan hak dan kewajiban yang adil kepada penyimpan dan peminjam modal LKM. Kewajiban dan hak anggota sebagai penyimpan dan peminjam dana diatur berdasarkan kesepakatan anggota sebagai pemilik LKM, atau dengan kata lain keadilan yang akan disalurkan melalui hak dan kewajiban dirumuskan berdasarkan kontrak sosial.

Berdasarkan hasil penelitian terhadap dalam 3 LKM yang modalnya milik masyarakat dan 2 LKM modalnya berasal dari pemerintah ditemukan bahwa LKM dibentuk berdasarkan kontrak sosial. Peraturan yang berlaku dalam LKM milik masyarakat ditetapkan berdasarkan kontrak sosial pengurus dan atau bersama anggota. Peraturan tersebut meliputi pemilihan pengelola, masa jabatan pengelola, tupoksi perngelola, besarnya simpanan pokok dan wajib, tingkat bunga, persyaratan pemijaman, cara mengembalikan pinjaman. 
Di dalam 2 LKM yang tidak memiliki modal sendiri atau menjadi penyalur dana dari pemerintah, semua peraturan yang berlaku didasarkan pada kontrak sosial yang ditentukan oleh lembaga eksternal yaitu pengelola dana di tingkat kecamatan. Peraturan tersebut meliputi peminjaman modal, besarnya bunga, jaminan dan cara mengembalikan ditentukan pemilik modal, dalam hal ini pemerintah melalui pengurus dana PNPM di tingkat Kecamatan, sedangkan pengurus LKM dan anggota wenang mengatur penggunaan dana kas yang menjadi milik anggota LKM. Di dalam LKM penyalur dana pemerintah ini tidak ada kewajiban bagi anggota untuk menyetor simpanan. Kontrak sosial menyepakati bahwa LKM tidak menerima simpanan anggota. Kedudukan LKM sebagai penyalur modal dari pemerintah ini ada kaitannya dengan program linkage, yaitu program yang menghubungkan bank dan pelaku usaha kecil dan menengah. Program ini merupakan kerjasama antara pihak pemilik modal, LKM dan pelaku usaha selaku debitur. Melalui program kerjasama ini masingmasing pihak diuntungkan, di mana pihak pemilik modal memperoleh penyerapan dana pembiayaan yang tersalurkan kepada pelaku usaha mikro, Pinjaman yang disalurkan melalui LKM di atas namakan LKM, artinya pihak debitur dalam perjanjian pinjam tersebut adalah LKM. Selanjutnya LKM membagikan kepada nggota sesuai dengan pinjaman yang diusulkan oleh masing-masing anggota. Dalam kajian penelitian lain, LKM memperoleh sumber dana pembiayaan dari pemerintah dan menyalurkan kepada pelaku usaha kecil menengah yang selama ini tidak mendapat akses pinjaman modal dari bank (Hamidah, 2015).

Kembali pada 3 LKM yang mengelola modal anggota, ditemukan peraturan tentang maksimum pinjaman bagi masing-masing anggota dan bunga ditentukan bersama oleh anggota dan pengurus LKM. Status bunga pinjaman menurut anggota merupakan penghasilan bagi LKM, dan setelah dikurangi biaya operasional dan dana cadangan sisanya sebagai keuntungan LKM. Biaya operasional meliputi pembelian alat tulis dan membayar uang lelah pengelola lembaga keuangan. Dana cadangan digunakan untuk menambah modal LKM.

Berkaitan dengan tingkat bunga yang dibebankan kepada debitur, baik LKM milik masyarakat maupun LKM penyalur dana pemerintah, memberlakukan tingkat bunga antara 1,5 -1,75 persen per bulan. Tingkat bunga ini tidak lebih tinggi daripada yang berlaku di LKM formal seperti koperasi simpan pinjam, juga 
membebani bunga 1,5 persen perbulan. Tingginya bunga yang berlaku dala LKM milik masyarakat merupakan hasil kesepakatan antara anggota dengan pengurus, sedangkan pada LKM penyalur dana pemerintah, tingkat bunga ditentukan oleh pemilik modal yaitu pemerintah c.q pengelola tingkat kecamatan. Jangka waktu pengembalian pinjaman dalam LKM milik sendiri 3 bulan, sedangkan dalam LKM penyalur dana pemerintah 12 bulan.

Sekalipun bunga pinjaman LKM milik masyarakat menjadi hak anggota, namun LKM tidak pernah membagi keuntungan dalam bentuk uang. Seluruh bunga dikumpulkan menjadi milik lembaga, yang digunakan untuk memperbesar modal lembaga, dan digunakan untuk kepentingan bersama misal wisata bersama, untuk biaya halal bihalal, dan sejenisnya. Sedangkan dalam LKM yang modalnya milik pemerintah bunga menjadi milik pengurus modal tingkat kecamatan. Bunga yang dibayar setiap bulan, diserahkan kepada pengelola di tingkat Kecamatan berikut angsuran bulanannya. Baik bunga maupun angsurannya yang diserahkan di atas namakan kelompok.

Berkaitan dengan jaminan 3

LKM milik masyarakat tidak mewajibkan adanya jaminan kebendaan (collateral free lending) untuk setiap pinjaman. Bagi anggota yang meminjam kepada LKM milik masyarakat jaminannya dapat dikategorikan sebagai jaminan kelompok, karena teman-temannya sendiri yang menjamin, melalui tangggung jawab renteng. Hal yang sama juga berlaku dalam LKM yang menjadi penyalur modal pemerintah setiap anggota yang memnjam modal diwajibkan menyerahkan jaminan yang bentuknya uang tunai sebesar Rp. 50.000, bagi setiap peminjam. Walaupun konsepnya sebagai jaminan namun uang tersebut tidak akan kembali kepada debitur yang telah melunasi pinjamannya. Uang jaminan tersebut dikumpulkan dan disimpan di LKM sebagai kekayaan LKM, dan akan difungsikan untuk melunasi utang anggota LKM yang gagal melunasi utang. Namun jika tidak ada anggota yang gagal bayar, maka uang jaminan menjadi milik LKM.

Tanggung jawab kelompok jamak terjadi dalam LKM yang melayani kelompok miskin. Hal ini ada dalam kedua jenis LKM sampel yang menjadi sasaran penelitian ini, dan jenis tanggung jawab ini merawat keberlanjutan eksistensi LKM. Walaupun tanggung jawab renteng berperan menjaga keberlanjutan LKM, namun ada kemungkin bentuk tanggung jawab demikian dapat disalah gunakan oleh peminjam atau tidak 
memenuhi kewajiban pribadinya membayar pinjaman (Marino, 2010).

Dalam penelitian ini tidak ditemukan peraturan perbankan yang mempengaruhi peraturan diterapkan dalam LKM milik masyarakat. Hal ini sama dengan temuan Mersland dan Strøm, yang menyatakan bahwa peraturan yang berlaku di lembaga perbankan tidak mempengaruhi peraturan yang berlaku di LKM (Mersland dan Strøm, 2009). Temuan penelitian ini menunjukkan bahwa LKM yang seluruh modalnya milik masyarakat cenderung lebih otonom dalam mengatur bunga maupun pembagian keuantungan pada semua anggota.

Beralih pada keadilan, Aristoteles mengartikan keadilan sebgai perilaku seseorang yang dilakukan dalam masyarakat dengan tidak mengambil keputusan yang bertentangan dengan nilai-nilai dasar individu untuk rasa kepedulian atas sesama manusia sebagai mahluk hidup didalamnya. Dalam rangka itu, Aristoteles membedakan 3 (tiga) macam keadilan, yaitu distributif, pemulihan, dan komutatif. Prinsip keadilan komutatif mengatur urusan transaksi antara pihak-pihak yang terlibat dalam pertukaran atau perdagangan.

Mengkaji keadilan yang yang terkandung dalam membagi keuntungan, membebani bunga serta resiko rugi ketika debitur gagal bayar, apabila mengacu pendapat Aristoteles, maka keadilan yang diterapkan adalah keadilan komutatif. Artinya berlaku hak dan kewajiban yang sama bagi semua anggota baik selaku debitur yang telah memberi jasa kepada lembaga maupun kreditur yang tidak memberi jasa kepada lembaga. Hal ini terjadi pada LKM milik masyarakat, di mana hak debitur yang telah memberikan jasa kepada lembaga sama dengan hak anggota lainnya yang tidak memberikan jasa kepada lembaga. Hak anggota selaku kreditur memperoleh keuntungan yang persentase sama besarnya hak anggota sebagai debitur yang telah memberi jasa kepada lembaga. Penetapan pembagian keuntungan yang diwujudkan dalam bentuk pembiayaan kepentingan bersama, dapat diitepretasikan bahwa bagian imbalan yang dinikmati semua anggota tidak didasarkan kepada besar kecilnya jasa anggota kepada LKM. Prinsip pembagian keuntungan ini biasanya berlaku dalam perusahaan Perserikatan Perdata (Pasal 1633) atau dalam Perseroan Terbatas, di mana besarnya modal yang diserahkan oleh anggota dalam kelompok menentukan besar kecilnya keuntungan yang diterima oleh masing-masing anggota. Dipandang dari prinsip perkoperasian penetapan pembagian ini tidak adil jika 
dipandang dari sisi anggota yang simpanan kecil, tetapi memberikan jasa besar kepada lembaga keuangan. Dalam prinsip koperasi anggota yang jasanya besar terhadap menerima keuntungan atau sisa hasil usaha lebih besar daripada anggota yang memiliki simpanan besar tetapi tidak pernah memberikan jasa kepada lembaga atau organisasinya. Pembagian keuntungan LKM milik masyarakat mencerminkan penghargaan yang sama terhadap anggota yang berjasa maupun yang tidak berjasa kepada lembaga. Pada sisi lain, keadilan komutatif juga dapat dilihat dari resiko yang harus ditanggung bersama oleh anggota LKM yang menyalurkan modal dari pemerintah. Bagi semua anggota harus menanggung resiko atas kemacetan angsuran yang dilakukan oleh seorang anggota. Tanggung jawab renteng resiko dapat diidentifikasi dari sumber modal yang digunakan untuk melunasi hutang debitur. Sumber modal tersebut berasal dari anggota lain yang pernah menyerahkan uang jaminan yang disimpan oleh LKM.

Kontrak sosial dalam menjalakan usaha kredit mikro di kalangan kelas bawah sebagimana dideskripsikan di atas dapat dikategorikan sebagai kontrak usaha yang tidak matematis, karena tidak mengitung jasa dan modal, tetapi lebih mengutamakan penghargaan mitra usaha dan keberlanjutan usaha. Sebagaimana dikemukakan oleh Hernoko, bahwa kontrak bisnis komersiel saat ini lebih mengutamakan adalah jaminan terhadap perbedaan kepentingan dari para pihak yang telah diatur dalam mekanisme pembagian beban secara proporsional, terlepas berapa proporsi hasil akhir yang diterima masing-masing pihak (Hernoko, 2016). Apa yang disimpulkan Hernoko mendasarkan pada kerangka pikir Rawls tentang keadilan yang berdasarkan kontrak, dapat diterapkan untuk menelaah beban kewajiban yang berlaku pada anggota LKM. Keadilan yang diimplementasi dalam hubungan antara LKM dengan anggotanya, di mana pihak anggota sebagai debitur memberikan penghasilan dalam bentuk bunga pada LKM, tetapi pada saat yang sama debitur juga mendistribusikan beban resiko pada anggota lain apabila tidak dapat mengembalikan utangnya kepada LKM.

\section{Simpulan}

LKM milik masyarakat yang mengelola modal sendiri lebih otonom daripada LKM yang menjadi penyalur modal dari pemerintah. LKM milik masyarakat yang mengelola modal anggota menentukan lembaga yang mengatur tentang masa pengurusan, simpanan pokok dan wajib, pinjaman, bunga, ketentuan pengembalian pinjaman, penyelesaian pinjaman yang bermasalah. Sedangkan 
LKM yang mengelola dana dari pemerintah hanya menentukan lembaga yang mengatur penggunaan kas. Perjanjian antara LKM dapat disebut sebagai insitusi yang berlaku bagi seluruh anggota LKM ketika berkedudukan sebagai debitur. dengan anggota sebagai debitur mengimplementasikan prinsip keadilan komutatif, semua debitur dan kreditur diperlakukan sama tanpa melihat jasa yang diberikan kepada debitur kepada lembaga.

\section{Rujukan}

Ana Maria Mareno. 2010. Garmeen Microfinance: An Evaluation of the Succeses and Limitation of the Grameen Bank, artikel dipublikasikan dalam https://repository.upenn.edu/cgi /viewcontent.cgi? article $=1016$ \&context=ppe_honors

Baskara, I Gede Kajeng. 2013. Lembaga Keuangan Mikro di Indonesia, artikel dalam Jurnal Buletin Studi Ekonomi Vol. 18, No. 2, Agustus 2013

Benjamin Fiegenberg, Erica M. Field, Rohini Pande, Building SocialCapital Through Micro Finance. Working Paper 16018

http://www.nber.org/papers/w16018

Hamidah, Siti. 2015. Analisis Kebijakan Linkage Program Lembaga Keuangan Syariah Dalam Rangka Pemberdayaan UKM di Indonesia. Artikel dalam ARENA HUKUM Vol. 8 No. 2 Agustus 2015. Malang. Universitas Brawijaya

Hendayana, Rachmat dan Sjahrul

Bustaman. 2007. Fenomena Lembaga Keuangan Mikro
Dalam Perspektif Pembangunan Ekonomi Perdesaan, Prosiding Balai Besar Pengkajia dan Penembangan Teknologi Pertanian diunduh dari https://pse.litbang.pertanian.go.id lind/pdf files/Pros_2007-A_1.pdf

Hernoko, Agus Yudo,. 2010. Keseimbanagan versus Keadilan Dalam Kontrak (Upaya Menata Struktur Hubungan Hukum Dalam Perspektif Kontrak Yang Berkeadilan) . Pidato pengukuhan Guru Besar, Surabaya, Universitas Airlangga

Mulyaningsih, Yani, Nunung Nuryantono, Rina Octaviani dan Carunia Firdausy. 2006. Trade-off Antara

Kesinambungan Keuangan dan Jangkauan Lembaga Keuangan Mikro Syariah di Perdesaan Jawa Barat, artikel dalam Jurnal Kajian Ekonomi dan Keuangan Vol. 20 No.1 Tahun 2006.

http//fiscaldepkeu.go.id/ejourna $l$

Parera, Benaya. 2016. Micro Financ Economic in Sri Lanka in Journalof Economic

Rawls, John. 2011. A Theoryof Justice, Teori Keadilan: Dasar-dasar Filasafat PolitikUntuk Mewujudkan Kesejahteraan Sosial dalam Negara (terjemahan). Yogyakarta. Pustaka Pelajar

Roy Mersland and R Øystein Strøm, Performance and governance in Microfinance Institutions, in Journal Of Banking And Finance, Volume 33, Issue 4, April 2009, 
page 662-669 diunduh dari https://www.sciencedirect.com/s cience/article/pii/S03784266080 $\underline{02835}$

Saptana, Saptana, Sri Wahyuni dan M Sehat Pasarbu. 2013. Strategi Percepatan Transformasi Kelembagaan Gapoktan Dan Lembaga Keuangan Mikro Agribisnis Dalam Memperkuat Ekonomi Di Perdesaan dalam Jurnal Manajemen dan Agrobisnis Vol 10 No. 1 IPB DOI: http://dx.doi.org/10.17358/j ma.10.1.60-70

Yunus, Muhammad. 2007. Credit for the Poor : Poverty as Distant History, artikel dalam Harvard International Review; Cambridge Vol. 29 Iss 3, ( Fall, 2007): 20-24 diunduh dari https://search.proquest.com/openvie w/e18775a5f2f56a6c3fd75c516e4f3 a29/1?pqorigsite $=$ gscholar \&cbl $=32013$

Perturan Perundang-undangan.

UU Nomor 1 Tahun 2013 tentang Lembaga Keuangan Mikro

Sumber Lain

http://www.berdesa.com/informasi-

lengkap-tentang-bumdes-yang-harus-

anda-ketahui/ diunduh 8 Mei 2019

https://www.bi.go.id/id/umkm/kredit/d

ata/Default.aspx diunduh 23

Agustus 2019

https://keuangan.kontan.co.id/news/ba

nkir-akui-gap-antara-laju-kreditdan-dpk-mulai- menyempit?page=all diunduh 19

Mei 2019

https://databoks.katadata.co.id/dat apublish/2016/09/01/akses-kreditperbankan-masyarakat-masihrendah diunduh 29 Mei 2019 